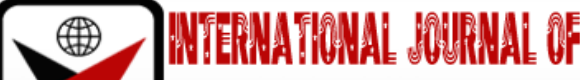 ZmRक
}

ISSN 2278-0211 (Online)

\section{Financial Sector Development and Economic Growth in Sub-Saharan Africa: A Dynamic Pool Mean Group Approach}

\author{
Theophilus Boufini \\ Doctoral Student, Department of Finance and Banking, \\ University of Port Harcourt, Choba, Nigeria \\ TorbiraLezaasi $\mathbf{L}$. \\ Senior Lecturer, Department of Finance and Banking, \\ University of Port Harcourt, Choba, Nigeria
}

\begin{abstract}
:
This study examines the effect of financial sector development on economic growth in sub-Saharan African countries using the dynamic pooled mean group estimation approach. The sample comprises six countries; Ghana, Kenya, Mauritius, Namibia, Nigeria and South Africa, while the time-series dimension of the data covers from 1995 to 2019. Our results generally suggest that financial sector development is an important factor for economic growth. However, while financial sector development affects economic growth through money supply in the short run, its long-run impact occurs through stock market performance, gross fixed capital formation and domestic savings. Increase in both credit to private sector ratio to GDP and government expenditure ratio to GDP has no effect on growth in both the short run and long run. Our results show that the selected sub-Saharan economies would converge to their long run equilibrium levels after suffering a shock. Therefore, our results support the view expressed many authors that the impact of financial development on growth depends on how the former is measured.
\end{abstract}

Keywords: Financial sector development, economic growth, pooled mean group

\section{Introduction}

It is well established in the literature that financial sector development plays an indispensable role in any economy. Financial sector development could be defined as a sustained improvement in the quantity, quality and efficiency of both direct and indirect services provided by financial markets and institutions (Calderón \& Liu, 2003). The financial system mobilizes financial resources from the surplus sector and channels them into productive uses, thereby laying the main foundation for economic growth. Hence, theoretically, financial sector development has a positive causal impact on economic growth.

Despite this well-established theoretical link, which has also since been confirmed by several influential studies (see for example, Goldsmith (1969), Mckinnon (1973) and Shaw (1973)), many scholars have expressed concerns that African countries may have a completely different scenario because their financial institutions and financial markets have remained both inefficient and largely underdeveloped despite undergoing several far-reaching interventionist reforms(Ahmad, Etudaiye-Muhtar, Matemilola \& Bany-Ariffin, 2016).Besides, studies have also indicated that African countries have been confronted with the challenges of economic growth as most of them have consistently reported low growth rate. This may simply suggest that the financial sector plays an insignificant role in African economies. It may also be the case that activities in the financial sector have negative economic implications in Africa. Therefore, there is good reason to conduct an empirical investigation on the effect of financial sector development on economic growth in subSaharan Africa.

Empirically, several studies have considered the impact of financial sector development on economic growth both in developed and developing countries. However, the results that emerged from these studies are mixed. For example, Odhiambo (2008) concluded that any claim that financial development is indispensably required for economic growth should be considered with extreme caution. According to Bijlsma, Kool and Non (2018), despite the two decades of extensive research in this subject area, researchers are yet to reach consensus on the empirical relationship between financial development and economic growth as the reported sign, size and significance of the coefficients linking finance to growth vary significantly both within and across studies. Also, as Ono (2017) and Bijlsma, Kool and Non (2018) observed, the differences in the estimated effects of financial development on growth may be due to factors such as measures used to indicate financial sector development, estimation methods used, the period covered, sampled countries, and the control variables used. This study therefore contributes to the empirical literature by considering the effects of financial development indicators on economic growth in sub-Saharan African (SSA) countries using the dynamic pooled mean group (PMG) framework. This empirical framework is mostly applicable for a panel dataset with longer time series 
dimension. Our panel data consist of six countries in SSA (Ghana, Kenya, Mauritius, Namibia, Nigeria and South Africa), observed for 25 years from 1995 to 2019, hence the PMG framework can capture most of the dynamic features regarding the relationship between financial development and economic growth.

The use of the PMG model also enables us to evaluate the claim that the reported inconsistent estimates of the effect of financial development is largely associated with studies that use either time series or panel data frameworks (Asteriou \& Spanos, 2019). The framework also allows for the comparison of results across different countries by estimating short-run coefficients for each individual country in the pooled sample, while estimating the same long-run coefficients for all countries in the sample. To our knowledge, this method of estimating the impact of financial sector development on economic growth has not been previously used in the context of sub-Saharan African countries. The remaining part of the study has the following structure. Section 2 contains both the theoretical framework and the review of empirical studies. Section 3 discusses the data and the empirical model. Section 4 contains the empirical analysis and results, while the study is concluded in Section 5.

\section{Literature Review}

\subsection{Theoretical Framework}

The relationship between financial sector development and economic performance can be examined in the context of supply-leading theory. This theory, which has a long history, argues that financial sector facilitates resource allocation as well as lays the foundation for technological innovations, hence it drives the economic growth process (Bagehot, 1873; Schumpeter, 1912). Consistent with this argument, Levine (1999) developed a theoretical model which explains the importance of financial sector in economic growth process. The model assumes that the financial sector drives economic growth by facilitating resource allocation across space and time in an environment that is best characterized by uncertainty. This primary function is motivated by market frictions such as information and transaction costs, and comprises five dimensions; namely, savings mobilization, resource allocation, corporate control, risk management and easing trading and exchange of goods and services. However, these functions affect the real economy through two channels: namely capital accumulation and technological innovations.

\subsection{Review of Empirical Studies}

There is much consideration of the relationship between financial sector development and economic performance in the empirical literature. Authors have used different approaches and methodologies to examine whether financial sector development has a direct impact on economic growth. Also, different measures of financial sector development have emerged from the empirical literature. However, these approaches and measures have yielded mixed empirical results. While some authors find evidence suggesting that financial sector development has a positive large effect on economic growth, others conclude that the role of the financial sector in economic growth is neutral or insignificant. There also studies whose evidence suggests that financial sector development retards economic growth.

The study by Christopoulos and Tsionas. (2004) provided evidence on the importance of financial development for economic growth focusing on 10 developing countries. They examined the long-run relationship between financial deepening and economic growth using panel-based vector error correction model and fully modified OLS technique. They found that there is only one cointegrating relationship between financial deepening, economic growth and other ancillary variables, with causality running from financial deepening to economic growth. This finding is consistent with the earlier findings reported by Calderón and Liu (2003). They employed the Geweke decomposition test to examine how financial development and economic growth are causally related using a pooled data of 109 developed and developing countries for the period from 1960 to 1994 . They found that financial sector development drives economic growth, although, the relationship between the two variables could best be described as a feedback process. They also found that the effect of financial deepening is more pronounced in the developing countries than the developed countries, while capital accumulation and productivity growth are the main channels through which financial development affects economic growth.

Hassan, Sanchez and Yu (2011) employed panel regressions to examine the effect of financial development on economic growth in developing (low- and middle-income) countries over the period from 1980 to 2007 . They found that financial development is positively related to economic growth in developing countries. They also found that the short run relationship between financial development and economic growth is a feedback process for most region, while it is a oneway causal process running from economic growth to financial development for poor regions. Their results also indicate that real sector variables such as government expenditure and trade are significant determinants of economic growth.

Iheanacho (2016) empirically considered the nexus between financial intermediary development and economic growth in Nigeria within the ARDL (Autoregressive Distributive Lag) framework. The sample comprises time series data for the period from 1981 to 2011 observed at annual frequency. The study found, amongst others, that financial intermediary development has no significant relationship with economic growth in the long run, but its short-run effect on growth is negative and significant.

Ono (2017) employed the VAR model to test the finance-growth relationship in Russia, controlling for oil prices and foreign exchange rates. Their data were obtained at quarterly frequency, while the sample was divided into two subperiods: subsample 1 covering from 1999 to 2008 and subsample 2 covering from 2009 to 2014 . They found that while the relationship between money supply and economic growth is governed by a feedback causal process in the first subsample period, there is no evidence of causality that runs from money supply to economic growth in the second subsample period. Bijlsma, Kool and Non (2018) conducted a meta-analysis on 68 empirical studies published in different 
journals to uncover the documented estimates of the impact of financial development on economic growth. Studies that were included in the analysis are only those that use private credit to GDP ratio to proxy financial development. They also distinguished between linear and loglinear econometric specifications. Among their findings is that controlling for publication bias, financial sector development has a positive effect on economic growth. However, this finding is true only for logarithmic specifications as linear estimates indicated no significant relationship between credit to the private sector and economic growth. Bist (2018) employed panel unit root and cointegration analysis to examine how financial sector development and economic growth are related in the long run-in low-income countries over the period from 1995 to 2014. The sample comprised a panel of 16 low-income countries both in Africa and outside Africa. They found that although credit extended to the private sector is very low-income countries, financial development has a long-run positive and significant impact on economic growth. This positive effect is also robust as it is confirmed by the evidence from timeseries analysis conducted on the individual countries.

Ibrahim and Alagidede (2018) examined the impact of financial and real sector growth on economic growth focusing using the system generalized method of moments (GMM). They used panel dataset comprising 29 countries in Sub-Sahara African region observed for 35 years from 1980 to 2014. Their results indicate, among other things, that although the financial sector drives economic growth, the extent to which finance affects growth depends significantly on the simultaneous growth of real and financial sectors.

Wang, Zhang, Ghadimi, Liu, Lim and Stanley (2019) employed a spatial econometric analysis to examine whether economic growth in the Beijing-Tianjin-Hebei (BTH) region is affected by regional financial development. Their sample comprised county-level data obtained from 174 geographical units in the BTH region in China for the period from 2007 to 2016. Their findings showed that while credit provided to the private sector by financial institutions significantly affected economic growth process, the effect of bank branches on economic growth is not significant.

\section{Methodology}

\subsection{Data}

In this study, our sample comprises unbalanced panel of six countries in the sub-Saharan African region covering the period from 1995 to 2019. The countries in the sample are Ghana, Kenya, Mauritius, Namibia, Nigeria and South Africa. economic growth is proxied by real GDP per capita, while credit to private sector, broad money supply and value stocks traded are used as indicators of financial sector development. Consistent with previous studies, we also include in our growth model other financial variables such as domestic savings, government expenditure (Hassan, Sanchez \&Yu, 2011) and gross fixed capital formation (Bist, 2018). All financial variables are expressed as a ratio of nominal GDP. All data were collected from the world development indicators and are analyzed in EViews.

Table 1 shows the descriptive statistics for the pooled data and the individual countries. Figures $1 \mathrm{a}$ to $1 \mathrm{~g}$ show the time series plot for the individual countries.

\begin{tabular}{|c|c|c|c|c|c|c|c|c|c|}
\hline Variable & Obs. & Statistics & Pooled & Ghana & Kenya & Mauritius & Namibia & Nigeria & South Africa \\
\hline \multirow[t]{4}{*}{ RGDPPC } & \multirow[t]{4}{*}{150} & $\bar{x}$ & 3880.22 & 1260.21 & 945.16 & 7362.62 & 4955.24 & 1960.94 & 6797.18 \\
\hline & & $\sigma$ & 2783.74 & 332.01 & 132.81 & 1943.67 & 884.01 & 454.28 & 745.42 \\
\hline & & $S$ & 0.49 & 0.48 & 0.85 & 0.29 & -0.03 & -0.16 & -0.41 \\
\hline & & $K$ & 2.01 & 1.74 & 2.42 & 1.87 & 1.52 & 1.45 & 1.44 \\
\hline \multirow[t]{4}{*}{ CPSR } & \multirow[t]{4}{*}{150} & $\bar{x}$ & 12.41 & 27.09 & 75.08 & 47.68 & 10.72 & 67.04 & 40.00 \\
\hline & & $\sigma$ & 2.83 & 3.49 & 19.03 & 5.10 & 3.48 & 5.58 & 26.67 \\
\hline & & $S$ & -1.13 & 0.68 & 0.06 & 0.07 & 0.98 & 0.11 & 0.47 \\
\hline & & $K$ & 3.69 & 2.63 & 1.86 & 1.97 & 3.47 & 2.75 & 2.17 \\
\hline \multirow[t]{4}{*}{ MSR } & \multirow[t]{4}{*}{150} & $\bar{x}$ & 48.73 & 27.03 & 38.28 & 94.07 & 48.47 & 18.14 & 66.39 \\
\hline & & $\sigma$ & 26.90 & 3.74 & 2.62 & 13.21 & 10.48 & 6.30 & 10.08 \\
\hline & & $S$ & 0.71 & 0.13 & 0.40 & 0.12 & 0.36 & -0.06 & -0.41 \\
\hline & & $K$ & 2.60 & 2.02 & 1.90 & 2.12 & 1.41 & 1.34 & 1.73 \\
\hline \multirow[t]{4}{*}{ VSTR } & \multirow[t]{4}{*}{140} & $\bar{x}$ & 11.62 & 0.40 & 1.51 & 2.71 & 0.33 & 1.29 & 59.17 \\
\hline & & $\sigma$ & 25.35 & 0.24 & 1.27 & 1.01 & 0.25 & 1.48 & 29.12 \\
\hline & & $S$ & 2.59 & 1.00 & 1.32 & 0.45 & 0.94 & 2.57 & 0.67 \\
\hline & & $K$ & 9.44 & 3.07 & 4.49 & 2.52 & 3.11 & 8.60 & 3.55 \\
\hline \multirow{4}{*}{ SAVR } & \multirow[t]{4}{*}{145} & $\bar{x}$ & 19.85 & 15.06 & 13.59 & 21.09 & 22.31 & 30.69 & 16.14 \\
\hline & & $\sigma$ & 8.53 & 6.27 & 3.62 & 5.12 & 7.81 & 10.19 & 1.06 \\
\hline & & $S$ & 1.08 & -0.66 & 0.82 & -0.02 & -0.42 & 0.42 & 0.16 \\
\hline & & $K$ & 4.75 & 1.97 & 3.82 & 1.50 & 2.35 & 2.26 & 1.63 \\
\hline \multirow[t]{4}{*}{ GEXPR } & \multirow[t]{4}{*}{149} & $\bar{x}$ & 105.83 & 113.68 & 111.43 & 105.34 & 110.96 & 93.52 & 99.56 \\
\hline & & $\sigma$ & 8.91 & 5.60 & 2.64 & 5.28 & 8.07 & 6.34 & 1.53 \\
\hline & & $S$ & -0.22 & -0.18 & -0.24 & -0.35 & 0.49 & -0.77 & -0.54 \\
\hline & & $K$ & 3.15 & 2.81 & 2.57 & 2.27 & 2.26 & 3.60 & 3.19 \\
\hline \multirow[t]{4}{*}{$\overline{\text { GFCF }}$} & \multirow[t]{4}{*}{149} & $\bar{x}$ & 21.18 & 21.66 & 18.42 & 22.01 & 22.26 & 24.45 & 18.38 \\
\hline & & $\sigma$ & 5.35 & 5.16 & 2.17 & 2.84 & 4.89 & 9.12 & 2.07 \\
\hline & & $S$ & 1.30 & -0.26 & 0.29 & -0.52 & 1.09 & 0.43 & 0.42 \\
\hline & & $K$ & 5.04 & 2.20 & 1.97 & 2.51 & 3.58 & 1.76 & 2.78 \\
\hline
\end{tabular}

Table 1: Descriptive Statistics for the Pooled Data and the Individual Countries 


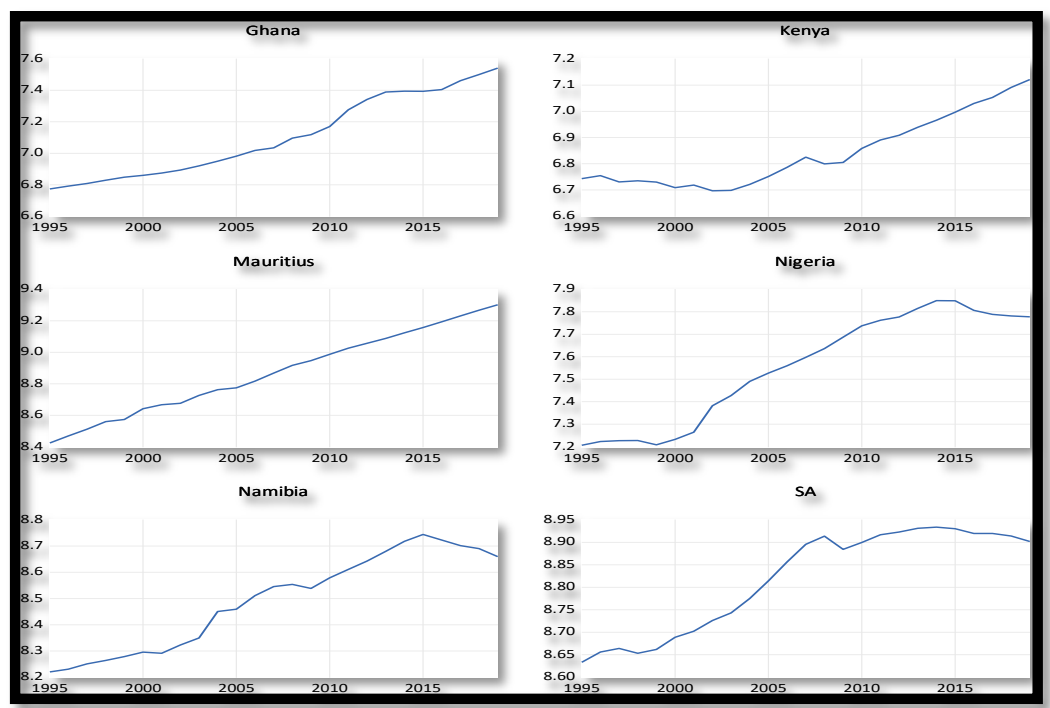

Figure 1: Real GDP Per Capita for the Individual Countries

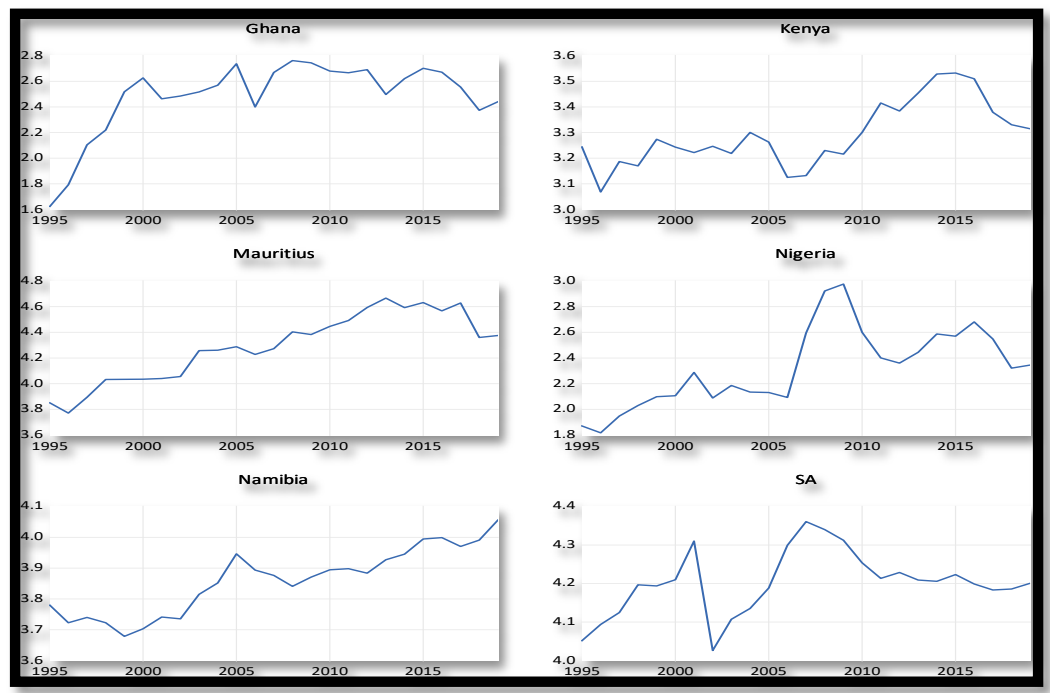

Figure 2: Credit to Private Sector for the Individual Countries

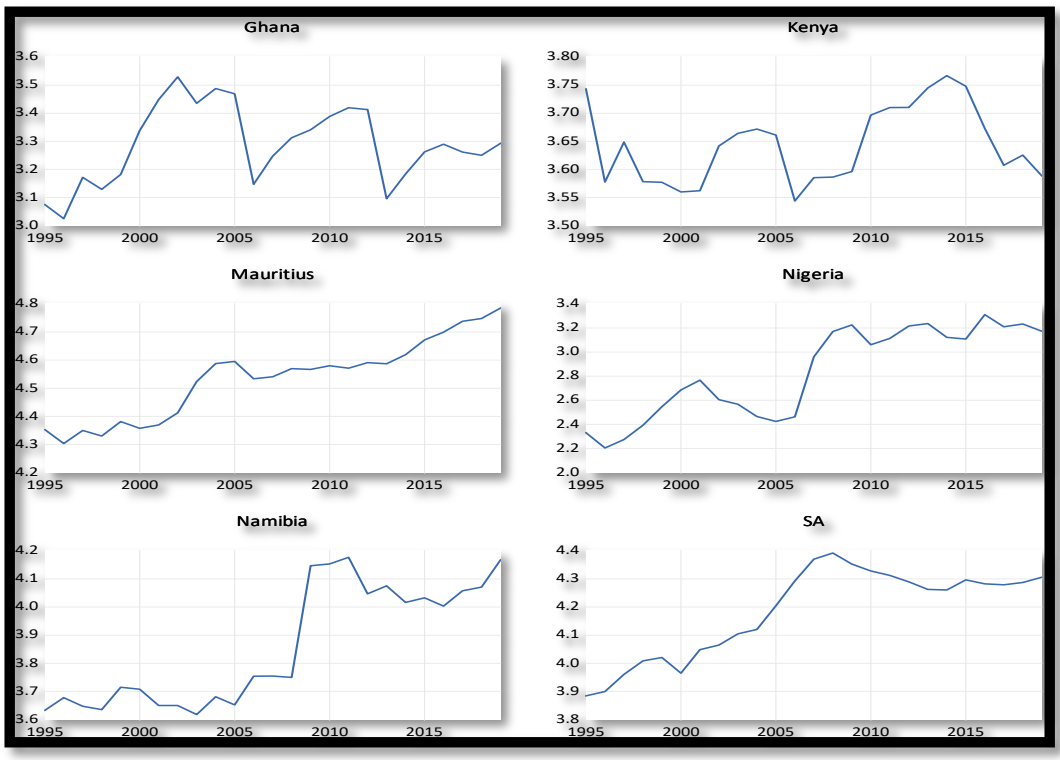

Figure 3: Broad Money Ratio for the Individual Countries 


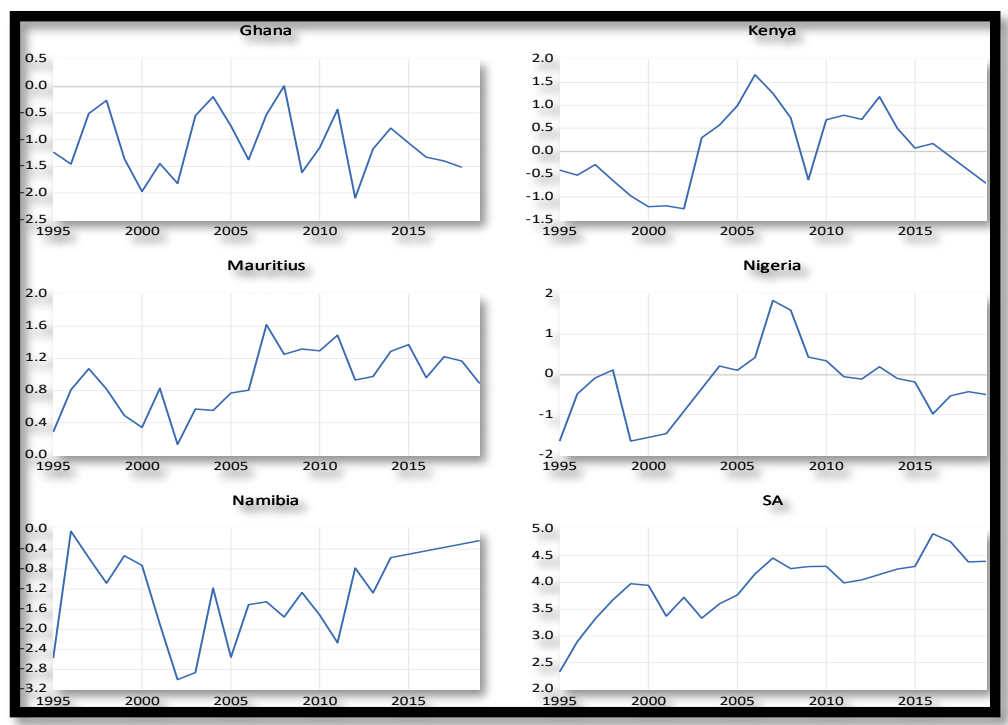

Figure 4: Value of Stock Traded for the Individual Countries

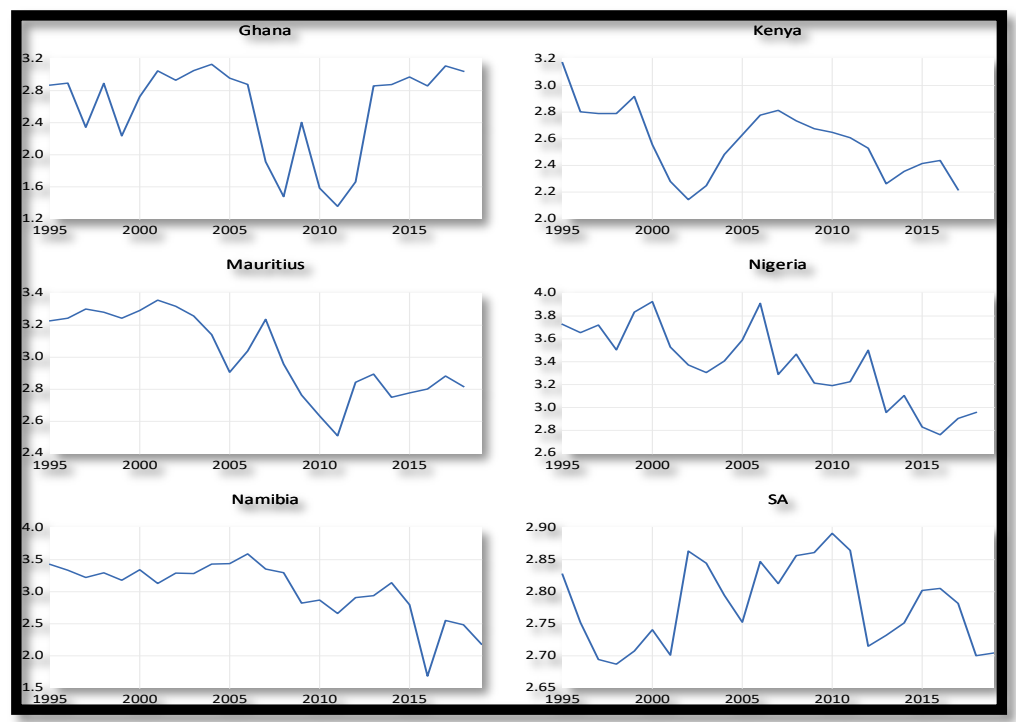

Figure 5: Domestic Savings Ratio for the Individual Countries

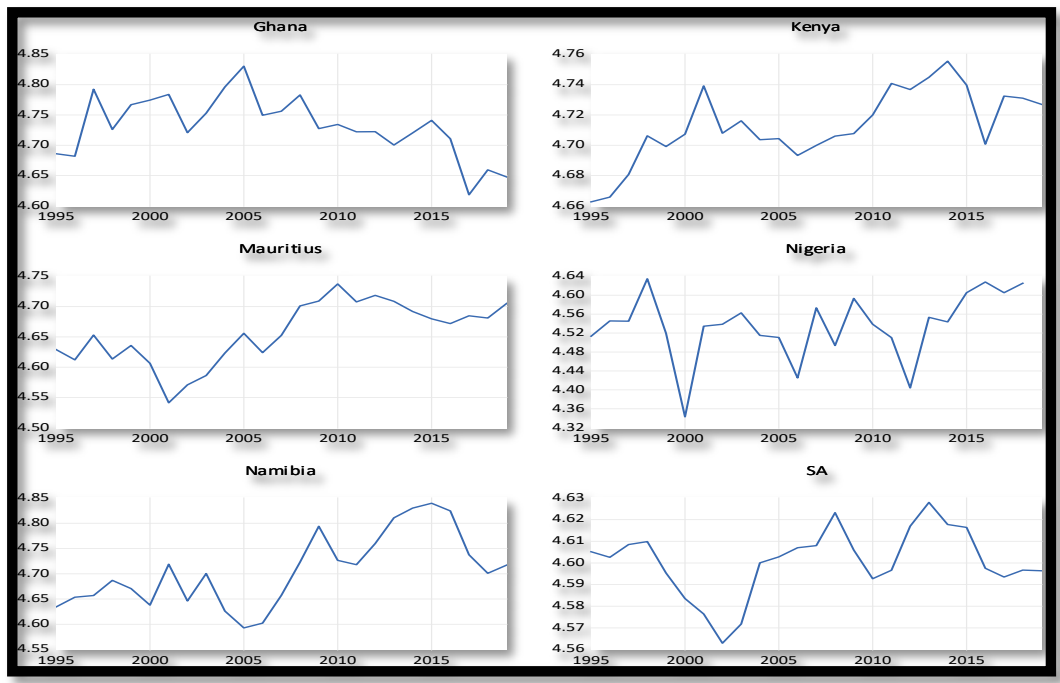

Figure 6: Government Expenditure for the Individual Countries 


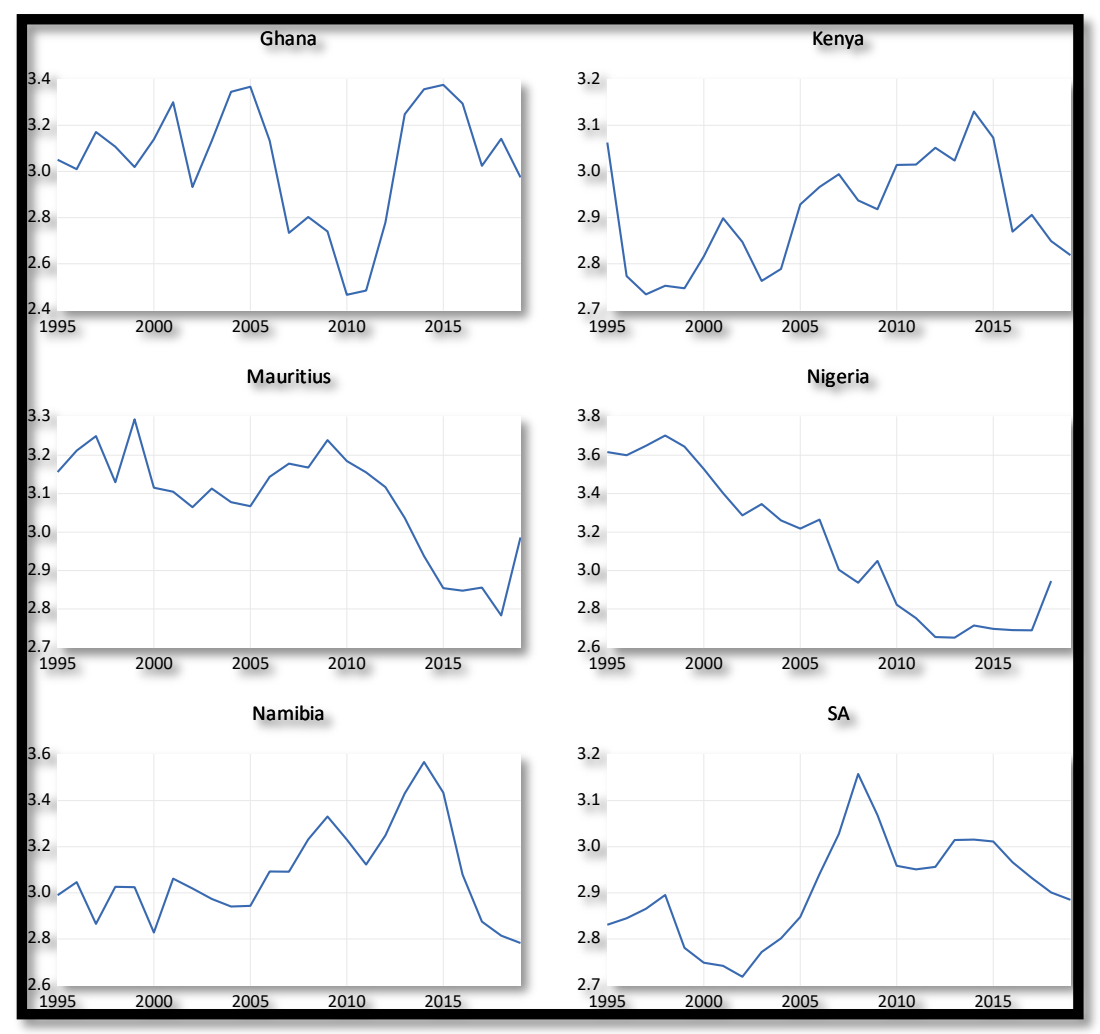

Figure 7: Government Fixed Capital Formation for the Individual Countries

\subsection{Model Specification}

To investigate the impact of financial sector development on economic growth, we employ the pooled mean group (PMG) empirical framework advocated by Pesaran, et al (1999), which according to Ahmad, Etudaiye-Muhtar, Matemilola and Bany-Ariffin (2016), is considered appropriate for dynamic panel data with longer time periods. Also, this framework is unique because it allows country by country comparison of results by estimating different constants, short-run coefficients and error correction coefficients for different countries. This approach can also be employed irrespective of whether the variables the same order integration or not. However, this framework restricts long-run coefficients to be the same for all countries, thereby not allowing the comparison of long-run coefficients, which may be considered as one of its limitations. Thus, the PMG framework assumes that the sampled countries can converge to the same long-run equilibrium growth but at different speeds, with the pace at which each country converges to this equilibrium level depending on its level of financial development.

We specify the pooled mean group (PMG) model for the impact of financial sector development on economic growth as follows:

$\triangle R G D P P C_{i t}=\phi_{i}\left(R G D P P C_{i t-1}-\beta_{1} C P S R_{i t}-\beta_{2} M_{S R}-\beta_{3} V S T R_{i t}-\beta_{4} S A V R_{i t}-\beta_{5} G F C F_{i t}-\beta_{6} G E X P R_{i t}-\beta_{0}\right)+$

$\lambda_{1} \Delta C P S R C_{i t}+\lambda_{2} \Delta M S R_{i t}+\lambda_{3} \Delta V S T_{i t}+\lambda_{4} \Delta S A V R_{i t}+\lambda_{5} \Delta G F C F_{i t}+\lambda_{6} \Delta G E X P R_{i t}+\gamma_{i}+\epsilon_{i t}$

Where RGDPPC = real GDP per capita, CPSR = credit to private sector ratio to GDP, MSR = money supply ratio to GDP, VSTR = value of traded stocks ratio to GDP, SAVR = savings ratio to GDP, GFCF = gross fixed capital formation ratio to GDP, and GEXPR = government expenditure ratio to GDP. All variables in the above model are log-transformed. Further, while $\beta_{i}$ represent long-run coefficients, $\lambda_{i}$ are short-run coefficients. Also, while $\epsilon_{i t}$ is the error term, $\phi_{i}$ is the error correction term, which is expected to be negative so that transient shocks in the model would give way for economic growth to return to its long-run equilibrium level.

\section{Empirical Analysis and Results}

Table 2 presents the results for the pooled mean group (PMG) regression. Long-run coefficients, short-run coefficients and speed of adjustment coefficient all are reported. The lag order is automatically chosen using the Schwarz information criterion (SIC). As this Table reveals, the signs of the short-run coefficients differ from those of the long-run coefficients for all variables, except for value of stocks traded whose coefficient maintains a positive sign for both models. Also, the long-run coefficients are generally higher than the short-run coefficients. Further, the adjustment coefficient (CointEq $(-1)=-0.0145$, p-value $=0.1891$ ) is not statistically significant, although, it is negative and less than unity, which is a necessary condition for economic growth to return to its equilibrium path after suffering an unexpected but transient shock. This may suggest that there is an adjustment mechanism from short run to long run-in economic growth across sub-Saharan countries. 


\begin{tabular}{|c|c|c|}
\hline Variables & Short-run Coefficients & Long-run Coefficients \\
\hline COINTEQ (-1) & -0.0145 & - \\
\hline LCPSR & $0.1891)$ & -0.0460 \\
& 0.0142 & $(0.9116)$ \\
\hline LMSR & $(0.4810)$ & 0.0478 \\
& $-0.0547^{* *}$ & $0.8791)$ \\
\hline LVSTR & $0.0401)$ & $0.3621^{* *}$ \\
& 0.0041 & $(0.0333)$ \\
\hline LSAVR & $(0.2261)$ & $4.6911^{*}$ \\
& -0.0172 & $-3.0752)$ \\
\hline LGFCF & $(0.4478)$ & $(0.0557)$ \\
\hline LGNER & 0.0526 & 10.575 \\
& $(0.1516)$ & $(0.1173)$ \\
\hline Constant & -0.1038 & - \\
\hline
\end{tabular}

Table 2: Pooled Mean Group (PMG) Results

() Contains $p$-values

* indicates significant at $10 \%$ level

** indicates significance at $5 \%$ level

The results show that credit to private sector ratio has a positive coefficient in the short run, but its long-run coefficient is negative. However, the p-values indicate that both short-run and long-run coefficients are not statistically significant. This implies that whereas the direction of the relationship between financial depth and economic growth varies from short run to long run, the effect of the former on the latter is statistically insignificant. In other words, the level of financial deepening does not matter for economic growth in sub-Saharan African countries. Although, our finding tends to be consistent with Iheanacho (2016), it contradicts supply-leading hypothesis as well as several previous empirical studies including Hassan Sanchez and Yu (2011), Christopoulos and Tsionas (2004), Ibrahim and Alagidede (2018), and Wang, Zhang, Ghadimi, Liu, Lim and Stanley (2019). One plausible explanation of this finding is that due to financial intermediation inefficiency which is associated with high information and transaction costs, financial institutions in SSA cannot effectively channel savings into the productive private sector, thereby playing an insignificant role in the economic growth process.

The results for broad money ratio show a negative and significant relationship with economic growth in the short run, but a positive and insignificant relationship in the long run. This shows that changes in broad money supply only have short-run implications. The short-run coefficient is estimated at 0.0547 which implies that, ceteris paribus, a $1 \%$ increase in broad money supply relative to nominal GDP would, on average, lead to approximately $0.05 \%$ decrease in real GDP per capita. This finding can be interpreted as suggesting that increase in broad money ratio to GDP hinders economic growth in the short run, but its effect neutralizes in the long run. This finding contradicts Calderón and Liu (2003) whose findings indicate, amongst others, that financial deepening, measured by the ratio of broad money to nominal GDP, has a more pronounced positive effect on economic growth in the developing countries.

Our results show that value of stocks traded ratio to nominal GDP has a consistent positive coefficient, indicating that stock market development leads to economic growth. However, while the effect of value of traded stocks is marginal and statistically insignificant in the short run, it is relatively large and significant at $5 \%$ level in the long run. The coefficient of 0.3621 shows that a $1 \%$ increase in the value of stocks traded relative to GDP would, on average, increase real GDP per capita by approximately $0.36 \%$ in the long run, holding other factors constant. This implies that although, stock market activities can enhance economic growth in SSA, its positive effect is appreciated only in the long run. Therefore, we argue that financial market performance affects only the long-run economic growth in sub-Saharan African countries.

The results show that domestic savings also has a mixed impact on economic growth. Theoretically, economic growth depends on savings mobilized through financial intermediation. The short-run effect of savings ratio is negative but insignificant, while its long-run effect is positive and significant at $10 \%$ level. This indicates that changes in domestic savings may have only a slightly negative effect on growth in the short run but would significantly increase growth in the long run. The long-run coefficient is estimated at 4.6911, which is quite substantial, indicating that the long-run growth effect of changes in domestic saving has policy implications. This also implies that for the selected SSA countries, the positive effect of any increase in domestic savings relative to nominal GDP can only be appreciated in the long run. Our results, which are consistent with Hassan, Sanchez and Yu (2011), therefore, agrees with the theoretical view that efficient conversion of domestic savings into investment is the main mechanism through which finance functions affect economic growth.

Our results also show that the effect of gross fixed capital formation ratio to GDP also varies from short run to long run. Whereas capital stock has a small positive and insignificant short-run coefficient, which is estimated at 0.0526 , its long-run coefficient (= -3.7096) is negative, quite large, and statistically significant at $10 \%$ level. This indicates that although, increase in gross fixed capital formation relative to GDP would slightly reduce economic activities in the short run, it would substantially increase economic growth in the long run. This is consistent with the financial intermediation 
theory which states that efficient allocation of financial resources increases the level of investment in the real sector, thereby leading to higher economic growth. This finding is also consistent with Khan, Khan, Jian and Khan (2020) but contradicts the results reported by Iheanacho (2016) and Bist (2018).

Finally, we find that government expenditure has no significant relationship with economic growth in both the long run and short run. However, while the short-run coefficient on government expenditure is small and negative, its long-run coefficient $(=10.575)$ is considerable and nearly significant at $10 \%$ level, hence it has policy implication. This implies that the positive effect of increasing government expenditure relative to GDP in the economy can be appreciated in the long run, despite having the tendency to reduce growth in the short run. This finding is consistent with Wang, Zhang, Ghadimi, Liu, Lim and Stanley (2019).

\section{Conclusions}

This study examines the effect of financial sector development on economic growth in sub-Saharan African countries using the dynamic pooled mean group estimation approach. The sample comprises six countries; Ghana, Kenya, Mauritius, Namibia, Nigeria and South Africa, while the time-series dimension of the data covers from 1995 to 2019. Economic growth is measured by real GDP per capita, while indicators of financial sector development used are credit to private sector ratio to GDP, broad money ratio to GDP and value of stocks traded to GDP ratio. Other financial variables: namely, domestic savings ratio to GDP, investment ratio to GDP and government expenditure ratio to GDP, are also included in the growth model. The main conclusions are as follows:

Our results generally suggest that financial sector development is an important factor for economic growth and the selected sub-Saharan economies would converge to their long-run equilibrium levels after suffering a shock. However, while financial sector development affects economic growth through money supply in the short run, its long-run impact occurs through stock market performance, gross fixed capital formation and domestic savings. Increase in both credit to private sector ratio to GDP and government expenditure ratio to GDP has no effect on growth in both the short run and long run.

Also, there is evidence that although, the short run effect of increase in the level of money supply on growth is negative, it has no long run effect. On the other hand, there is a positive long run growth effect of an increase in both value of stock market transactions relative to GDP and domestic savings relative to GDP, while the long run growth effect of an increase in gross fixed capital formation is negative.

Overall, the study is largely successful as its objectives were all achieved. Based on the reported findings, we conclude that the impact of financial sector development on economic growth in sub-Saharan African countries largely depends on how the latter is measured.

\section{References}

i. Ahmad, R., Etudaiye-Muhtar, O. F., Matemilola, B. T., \& Bany-Ariffin, A. N. (2016).

ii. Financial market development, global financial crisis and economic growth: evidence from developing nations. Portuguese Economic Journal, 15(3), 199-214.

iii. Asteriou, D., \& Spanos, K. (2019). The relationship between financial development and economic growth during the recent crisis: Evidence from the EU. Finance Research Letters, 28, 238-245.

iv. Bagehot, W. (1873). Lombard Street: A description of the money market, London: Henry S. King and Co.

v. Batuo, M., Mlambo, K., \& Asongu, S. (2018). Linkages between financial development, financial instability, financial liberalisation and economic growth in Africa. Research in International Business and Finance, 45, 168-179.

vi. Bijlsma, M., Kool, C., \& Non, M. (2018). The effect of financial development on economic growth: A metaanalysis. Applied Economics, 50(57), 6128-6148.

vii. Bist, J. P. (2018). Financial development and economic growth: Evidence from a panel of 16

viii. African and non-African low-income countries. Cogent Economics \& Finance, 6(1), 1-17.

ix. Calderón, C., \& Liu, L. (2003). The direction of causality between financial development and economic growth. Journal of development economics, 72(1), 321-334.

x. Christopoulos, D. K., \& Tsionas, E. G. (2004). Financial development and economic growth: Evidence from panel unit root and cointegration tests. Journal of development Economics, 73(1), 55-74.

xi. De Gregorio, J., \& Guidotti, P. E. (1995). Financial development and economic growth. World development, 23(3), 433-448.

xii. Goldsmith, R. W. (1969). Financial structure and development (No. HG174 G57).

xiii. Hassan, M. K., Sanchez, B., \& Yu, J. S. (2011). Financial development and economic growth: New evidence from panel data. The Quarterly Review of Economics and Finance, 51(1), 88-104.

xiv. Ibrahim, M., \& Alagidede, P. (2018). Effect of financial development on economic growth in sub-Saharan Africa. Journal of Policy Modeling, 40(6), 1104-1125.

xv. Iheanacho, E. (2016). The impact of financial development on economic growth in Nigeria: An ARDL analysis. Economies, 4(4), 26.

xvi. Khan, H., Khan, U., Jiang, L. J., \& Khan, M. A. (2020). Impact of infrastructure on economic growth in South Asia: Evidence from pooled mean group estimation. The Electricity Journal, 33(5), 106735.

xvii. Levine, R. (1999). Financial development and economic growth: views and agenda. Journal of Economic Literature, 35(2), 688-726.

xviii. McKinnon, R. I. (1973). Money and capital in economic development. Brookings Institutions Press. 
xix. Odhiambo, N. M. (2008). Financial depth, savings and economic growth in Kenya: A dynamic causal linkage. Economic Modelling, 25(4), 704-713.

$x x$. Ono, S. (2017). Financial development and economic growth nexus in Russia. Russian Journal of Economics, 3(3), 321-332.

xxi. Schumpeter, J. A. (1912). 1934. The theory of economic development.

xxii. Shaw, E. S. (1973). Financial deepening in economic development. New York: Oxford University Press

xxiii. Wang, C., Zhang, X., Ghadimi, P., Liu, Q., Lim, M. K., \& Stanley, H. E. (2019). The impact of regional financial development on economic growth in Beijing-Tianjin-Hebei region: A spatial econometric analysis. Physica A: Statistical Mechanics and its Applications, 521, 635-648. 